PROCEEDINGS OF THE UNITED STATES NATIONAL MUSEUM

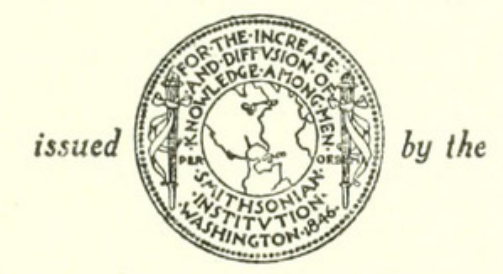

SMITHSONIAN INSTITUTION

U. S. NATIONAL MUSEUM

\begin{tabular}{lll}
\hline \hline Vol. 108 & Washington : 1959 & No. 3409 \\
\hline \hline
\end{tabular}

\title{
SCARAB BEETLES OF THE GENUS BOTHYNUS IN THE UNITED STATES (COLEOPTERA: SCARABAEIDAE) ${ }^{1}$
}

\section{By O. L. Cartwright}

Since Col. Thomas Casey's (1915) study of the scarab beetles of the genus Bothynus, which he placed in Ligyrus and Ligyrodes, the number of species has varied from the 31 he accepted to only six species accepted by L. W. Saylor in 1946. Casey described species based on minor variations, while Saylor's lumping of so many together under the name Ligyrus gibbosus (DeGeer) was based on obvious but superficial similarities. I agree that all of Casey's species are synonyms, but I do not agree with Saylor's placing of them. Two of the LeConte species which Saylor placed in synonymy are perfectly valid.

I have examined the Casey types in the U. S. National Museum and the LeConte types in the Museum of Comparative Zoology at Harvard College. After studying several thousand specimens, my conclusions regarding the species discussed by Dr. LeConte almost exactly 100 years ago are practically identical with the opinions expressed by him. The few species found since Dr. LeConte's day bring the total I recognize from the United States to nine species and one subspecies.

In the following account, changes in the nomenclature of the group are discussed, a key is presented for separation of the species, and for each species are given the synonyms, a complete description, a figure of the male genitalia, location of the type, number of specimens

1 This study was supported in part by a research grant from American Philosophical Society, Penrose Fund No. 2057. 
examined, and a map showing the distribution in the United States.

Many specimens were borrowed from other museums and private collections to supplement the material in the United States National Museum. I thank sincerely the following who made such loans: (from museum collections) E. B. Britton, British Museum (Natural History); A. E. Brower, State of Maine Forest Service; W. J. Brown, Canadian Department of Agriculture; M. A. Cazier, American Museum of Natural History; Leland Chandler and J. V. Osmun, Purdue University; E. A. Chapin, Museum of Comparative Zoology; Henry Dietrich, Cornell University; S. W. Frost, Pennsylvania State University; Walter B. Jones, Geological Survey of Alabama; Ralph Dury, Cincinnati Museum of Natural History; J. N. Knull, Ohio State University; Hugh B. Leech, California Academy of Sciences; H. O. Lund, University of Georgia; Rene Malaise, Naturhistoriska Riksmuseum; Frances McAlister, Clemson College; A. T. McClay, University of California (Davis, Calif.); H. E. Milliron, University of Delaware; W. D. Newsom, University of Louisiana; L. W. Quate, University of Nebraska; H. J. Reinhard, Agricultural and Mechanical College of Texas; M. W. Sanderson, Illinois Natural History Survey; H. C. Severin, University of South Dakota; A. N. Tissot, Florida Agricultural Experiment Station; H. V. Weems, Jr., Florida State Plant Board; F. G. Werner, University of Arizona; D. L. Wray, North Carolina Department of Agriculture; (from private collections) L. J. Bottimer, J. F. Brimley, H. L. Dozier, H. F. Howden, Gayle Nelson, F. H. Parker, William Rosenberg, and R. B. Selander.

I am especially grateful to Dr. Rene Malaise of the Riksmuseum in Stockholm, to Dr. Bengt-Olof Landin, Universitetets Zoologiska Institution, Lund, and to Dr. E. B. Britton of the British Museum (Natural History) for invaluable help in checking type specimens in their respective museums.

\section{Genus Bothynus Hope, 1837}

Bothynus Hope, 1837, p. 95.-Burmeister, 1847, p. 115.-LeConte, 1847, p. 86.Lacordaire, 1856, p. 413.-Prell, 1936, p. 146.

Ligyrus Burmeister, 1847, p. 542.-Casey, 1915, p. 178.-Arrow, 1937, p. 36.Saylor, 1946, p. 41.

Tomarus Erichson, 1847, p. 95.

Ligyrodes Casey, 1915, p. 178.

Euligyrus Casey, 1915, p. 185.

Grylius Casey, 1915, p. 189.

Anagrylius Casey, 1915, p. 204.

Ligyrellus Casey, 1915, p. 206.

Type of genus: Geoirupes cuniculus Fabricius.

The genus Bothynus was erected by the Rev. F. W. Hope in 1837 for two species, Geotrupes cuniculus Fabricius and Scarabaeus ascanius 
Kirby. He specifically designated Geotrupes cuniculus as type of the genus, gave a description, but did not mention a type locality. Casey (1915) designated Corynoscelis quadridens Taschenberg as type of the genus, overlooking Hope's previous designation.

Burmeister (1847) was unable to place G. cuniculus Fabricius but thought it was likely a small Podalgus.

Lacordaire (1856) stated that Hope harl made Geotrupes cuniculus Fabricius the type of Bothynus but said the species could not be determined, that he did not recognize it any more than did Burmeister, and suggested S. ascanius Kirby as the type of the genus.

Bates (1888) did not mention cuniculus Fabricius in either Geotrupes or Bothynus but placed tumulosus Burmeister (a synonym) in Ligymes.

Prell (1936) noted that Hope had designated Geotrupes cuniculus Fabricius as type of the genus Bothynus and that the Fabrician species was identical with Ligyrus tumulosus Burmeister. However, he stated that Hope's description of the genus Bothynus did not fit this species, that Hope very evidently had before him a species from the group which is limited in distribution to the Continent and which was designated by Burmeister as Podalgus (or Scatophilus). Prell then decided that B. cuniculus Hope, 1837 (not Fabricius 1801), was an undescribed species, the name Bothynus Hope, 1837, lost its validity, and that Bothynus Burmeister, 1847, with the type species Geotrupes medon Germar, 1824 (=B. ascanius Burmeister, 1847, nec Kirby, 1818), took its place.

Even though Hope described in his genus Bothynus a species which he mistakenly thought was cuniculus Fabricius, and which in reality was therefore without a valid name, perhaps not even congeneric with cuniculus Fabricius, he nevertheless first specifically stated the type of Bothynus to be Geotrupes cuniculus Fabricius, and I accept that species as the type. It might be pointed out that it is generally agreed the designation of a species as type of a genus is not to be rejected on the ground that the original author of the generic name misidentified that species.

Since Bothynus cuniculus (Fabricius) is congeneric with Ligyrus gibbosus (DeGeer), type of the genus Ligyrus, all of our species of Ligyrus should be placed in Bothynus. The name Scatophilus Burmeister, 1847 , remains available for those species recently assigned to Bothynus.

\section{Lectotype Designations}

Two specimens in the original Fabricius collection in the Kiel Museum in Kiel, Germany, were examined for me by Dr. Bengt-Olof Landin, and the male bearing an old label, "cuniculus," written in an old handwriting, probably Fabricius' own, was selected to be designated lectotype of the species. Dr. Landin has attached the following 
label, "Lectotypus Geotrupes cuniculus Fabr. Design. 1957 B.-O. Landin." He states that the lectotype is "comparatively well preserved: both antennae, and left meso- and metatarses are unbroken." He provided sketches of the clypeal teeth, foretibia, tip of the prosternal process and the male genitalia. A male from St. Croix, Virgin Islands, sent for comparison with the type, was returned with Dr. Landin's statement that it agreed completely with the lectotype.

Dr. Britton informs me that lectotypes have not been officially chosen for the Bates species, Ligyrus sallaei, L. laevicollis, and $L$. latifovea, but that a specimen in each series bears the name label in Bates' handwriting, also a red "Type" label, and that these have been unofficial lectotypes for many years. I select these specimens as lectotypes. Sex and localities for these lectotypes as given on the labels are as follows:

sallaei: $\sigma^{7}$, Almolonga, Mexico. (Höge.)

laevicollis: $\sigma^{x}$, Acapulco, Guerrero. (Höge.)

latifovea: $\&$, Teapa, Mexico. Salle Collection.

\section{Classification and Morphology}

The genus Ligyrus, here considered as a synonym of the true Bothynus, was placed by Casey in the tribe Pentodontini of the subfamily Dynastinae. Arrow (1937) placed the genus in the tribe Oryctini, with all of Casey's genera listed above as subgenera.

The species agree in the following characters: labial palpi inserted at the sides of the mentum which is narrowed in front; mandibles prominent and toothed externally; head with a strong transverse carina, sometimes reduced to two widely spaced tubercles; clypeus more or less triangular, reflexed, with two erect teeth at apex; pronotum frequently with an apical tubercle and anterior depression; elytra with four pairs of oblique geminate striae, stridulating organs on inner surface; the claws equal except on fore tarsi in males of a few species, anterior tarsi not elongate in male; the anterior coxae transverse, not prominent; posterior tibiae expanded apically, more or less truncate and ciliate; aedeagi usually distinct but similar in structure.

The genus is American, ranging from Canada to Argentina and Chile. Arrow listed 52 species in the Junk catalog, but included 24 of the Casey species here considered synonyms. Probably 40 or more species are to be found throughout the Western Hemisphere.

A few species are of economic importance. Bothynus gibbosus (DeGeer) is known as the carrot beetle in economic literature. Various species have been recorded as attacking carrot, celery, parsnip, beet, potato, cabbage, corn, cotton, sunflower, dahlia, amaranthus, and other crops and weeds. 


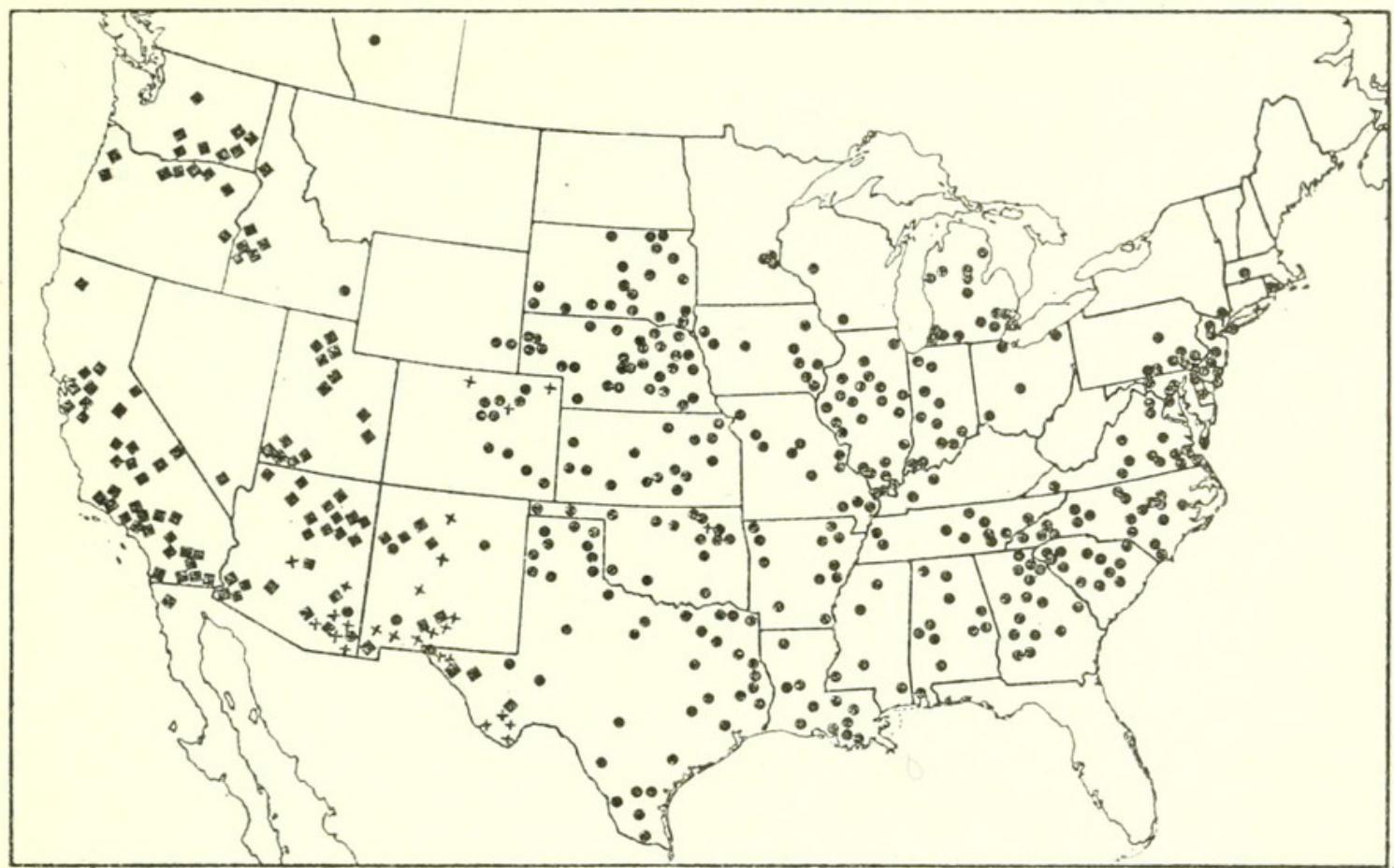

Figure 1.-Distribution in the United States of: Bothynus gibbosus gibbosus (DeGeer) (1); B. g. obsoletus LeConte (间); and intermediates of the two (X).

The species inhabiting the United States and Canada superficially are of two forms, the large, dark colored, more elongate species typified by relictus (Say), and the smaller, shorter, reddish brown species closely allied to gibbosus (DeGeer). Intermediate forms occur in Central and South America. Several subgenera may be represented but their limits cannot be defined until a more complete revision of

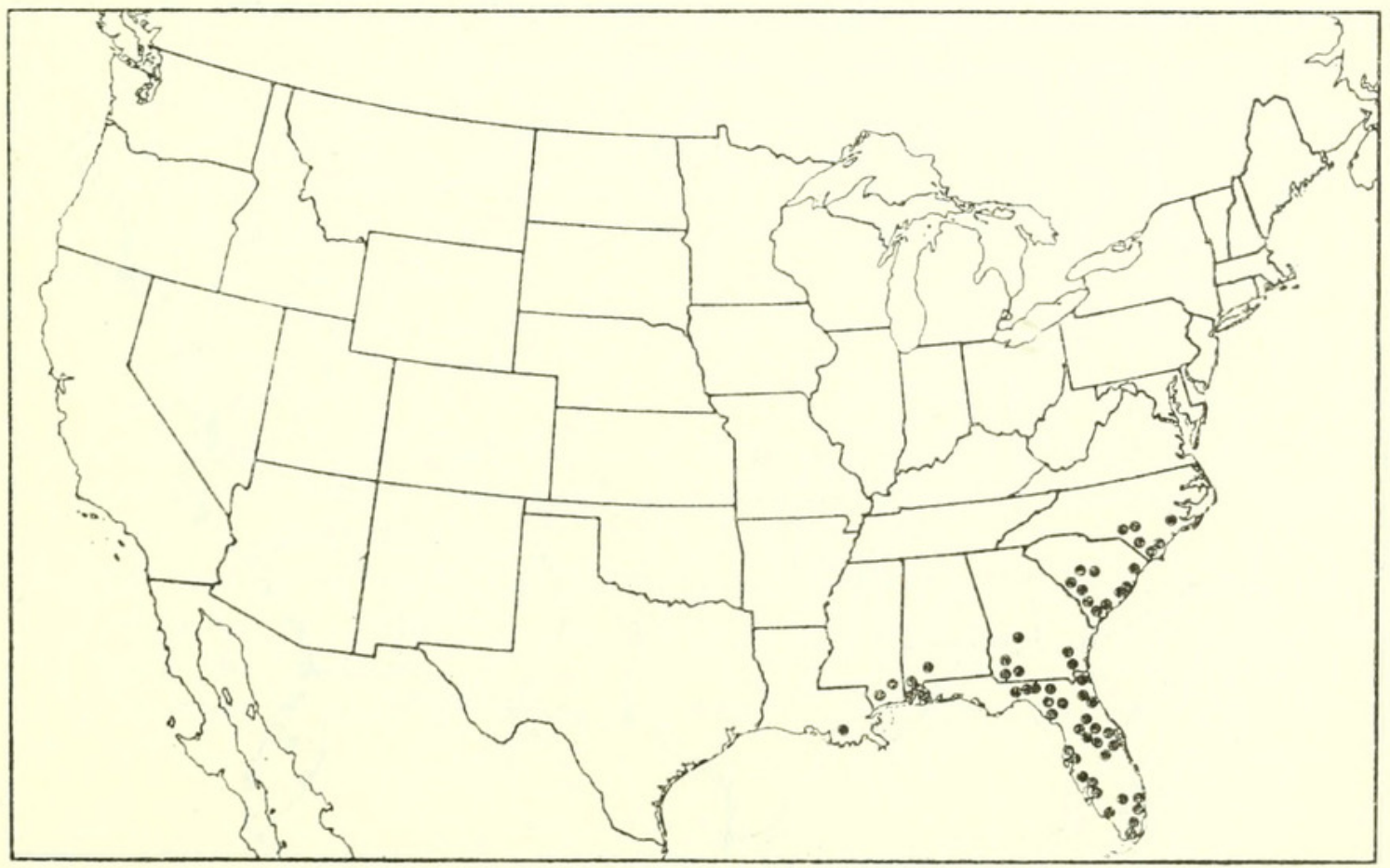

Figure 2.-Distribution of Bothynus neglectus LeConte in the United States. 


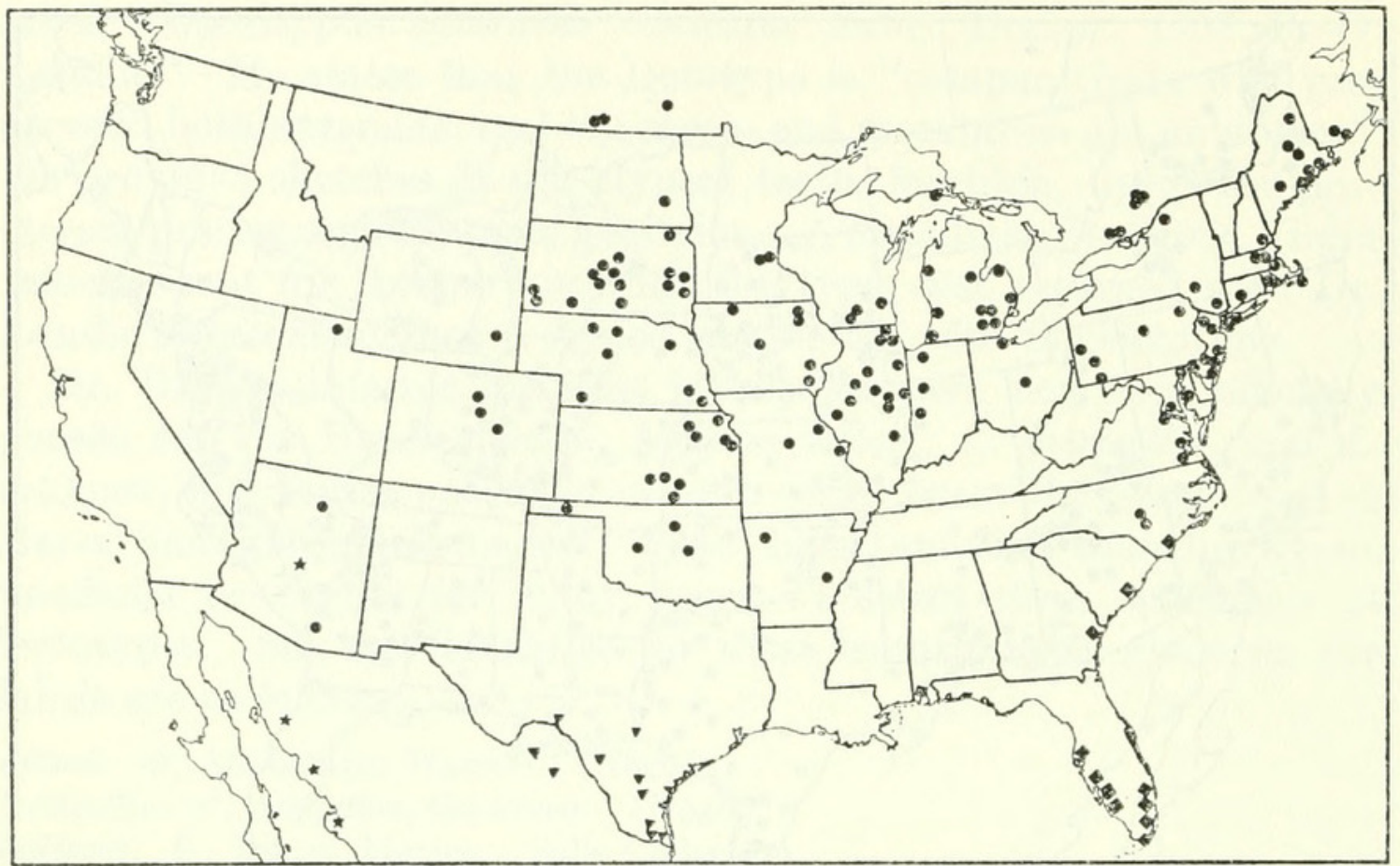

Figure 3.-Distribution in the United States of: Bothynus relictus (Say) (•); B. subtropicus

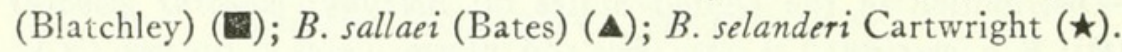

the entire group is undertaken. The gibbosus group is usually mixed and partly misidentified in most collections. Oxygrylius ruginasus (LeConte) and $O$. peninsularis Casey with similar color, form, punctures, pronotal impression, and denticle are frequently included as well. Oxygrylius, however, is easily separated from Bothynus by the clypeus being produced medially to a single, sharp, upturned tooth, while Bothynus always ends anteriorly in two teeth or denticles.

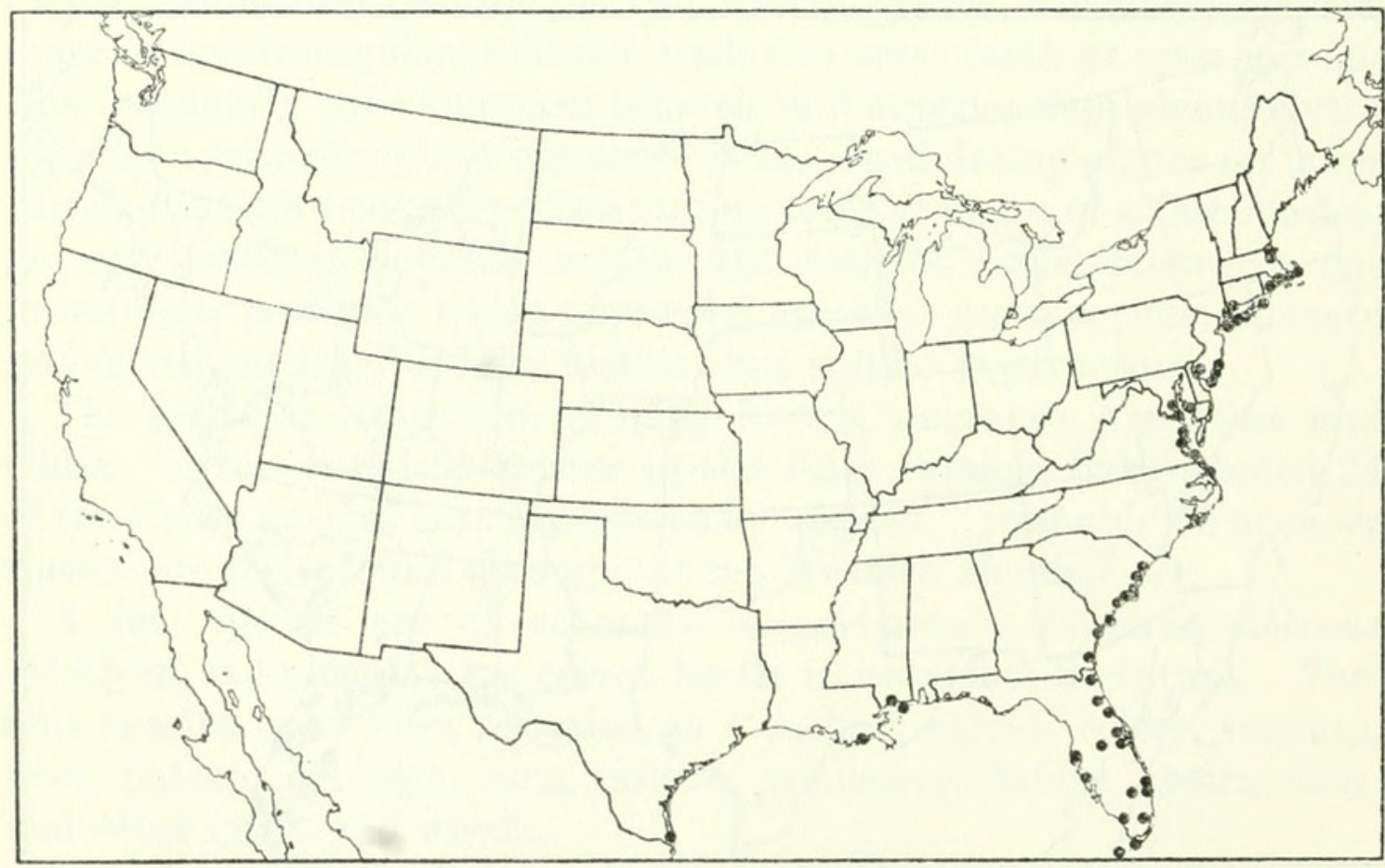

Figure 4.-Distribution of Bothynus morio LeConte in the United States. 


\section{Key to species of Bothynus of the United States}

1. Apex of prosternal process behind anterior coxae completely hairy; smaller species usually less than $18 \mathrm{~mm}$. in length . . . . . . . . . . . . . . 2

Apex of prosternal process at least partly nude; larger species usually more than $18 \mathrm{~mm}$. in length . . . . . . . . . . . . . . . . . . . . . . 5

2. Outer anterior face of fore tibia smooth adjacent to longitudinal row of coarse setigerous punctures (fig. $6 f$ ) . . . . . . . . . . . . . . . . . . . 3

Outer anterior face of fore tibia closely, finely to roughly punctulate adjacent to longitudinal row of coarse setigerous punctures (fig. $6 e$ ) . . . . . . 4

3. Punctures of pronotum and elytra very coarse; habitus as in gibbosus (DeGeer); coastal plain; North Carolina to Louisiana.

neglectus LeConte

Punctures of pronotum and elytra fine to very moderate; habitus slightly more elongate; found in sandy areas of seacoast; Massachusetts to Texas.

morio LeConte

4. Hind tibia short and wide, length of inside edge usually less than twice as long as apical width; first segment of posterior tarsus apically noticeably widened laterally, the width often more than the length of the $2 \mathrm{~d}$ segment; punctures of elytra not so noticeably annular, closer and smaller, more nearly uniform near margin around apical third; pronotum noticeably convex below lateral margins; larger than typical gibbosus; usually west of Rocky Mts. . . . . . . . . . . . . . . . . gibbosus obsoletus LeConte

Hind tibia longer and not so wide, length of inside edge more than twice the apical width; first segment of posterior tarsus with sides nearly straight, not wider than length of $2 \mathrm{~d}$ segment; elytral punctures usually distinctly annular; pronotum not noticeably convex below lateral margin; east of the Rocky Mts. . . . . . . . . . . . . . . gibbosus gibbosus (DeGeer)

5. Pronotum without apical impression; male anterior claw joint swollen, the anterior claw broad and abruptly bent at base. . . . . . . . . . . . 6

Pronotum with at least a small apical impression; male anterior claw and its joint normal . . . . . . . . . . . . . . . . . . . . . . 7

6. Anterior tibia normal, only three large teeth; pygidiurt soabriculate and closely, finely to moderately punctate at base and sides; middle and northeastern United States, eastern Canada. . . . . . . . . . relictus (Say)

Anterior tibia with an additional small but distinct tooth between the $2 \mathrm{~d}$ and $3 \mathrm{~d}$ large teeth; pygidium moderately coarsely punctate, the punctures evenly scattered throughout, a very little scabriculate sculpture at extreme base; southern Texas. . . . . . . . . . . . . . . sallaei (Bates)

7. Frontal carina widely interrupted at middle and joining lateral carina at sides; clypeal teeth widely separated; size moderate, 14 to $20 \mathrm{~mm}$.; tip of Florida and West Indies . . . . . . . . . . . . . . . cuniculus (Fabricius)

Frontal carina interrupted but not reaching sides, or reduced to two widely separated, conical tubercles; clypeal teeth usually separated by less than their basal width; size large, 24 to $29 \mathrm{~mm}$. . . . . . . . . . . . . . 8

8. First wide elytral interval outside sutural stria smooth and shining, rarely with fine punctures but always without the coarse punctures found on the next two intervals. . . . . . . . . . . . . laevicollis (Bates) First wide interval with coarse punctures as found on next two . . . . . 9 
9. Coarse punctures of all elytral intervals similar, shallow and indistinct to moderately deep; apex of prosternal process divided by a distinct groove, the anterior part nude, smooth and convex, the posterior part hairy; frontal rugae appearing as sharply delimited ridges on a flat surface; Arizona, Mexico.

selanderi, new species

Coarse punctures of all elytral intervals deep and distinct; prosternal process not divided, the nude apex with uneven surface, the long coarse hairs invading the nude area from back and sides; frontal rugae sharply delimited only on posterior side, not delimited anteriorly; North Carolina to Florida to Alabama . . . . . . . . . . . . . . subtropicus (Blatchley)

\section{Bothynus gibbosus gibbosus (DeGeer)}

Scarabaeus gibbosus DeGeer, 1774, p. 322.

Geotrupes juvencus Fabricius, 1775, p. 32.

Podalgus variolosus Burmeister, 1847, p. 121.

Podalgus juvencus Burmeister, 1847, p. 121.

Ligyrus juvencus Burmeister, 1847, p. 542.

Ligyrus gibbosus LeConte, 1856, p. 20.

Ligyrus parallelus Casey, 1915, p. 194.

Ligyrus puncticauda Casey, 1915, p. 195.

Ligyrus texanus Casey, 1915, p. 195.

Ligyrus breviusculus Casey, 1915, p. 196.

Ligyrus lacustris Casey, 1915, p. 196.

Ligyrus laticauda Casey, 1915, p. 197.

Ligyrus laetulus Casey, 1915, p. 197.

Ligyrus bicorniculatus Casey, 1915, p. 198.

Ligyrus rubidus Casey, 1915, p. 198.

Ligyrus curtipennis Casey, 1915, p. 199.

Ligyrus lucublandus Casey, 1915, p. 199.

Ligyrus farctus Casey, 1915, p. 200.

Length 10 to $17 \mathrm{~mm}$., width 6 to $11 \mathrm{~mm}$. Oblong-oval, convex, shining, reddish brown. Clypeus apically bidentate, the teeth separated by their basal width, surface finely rugulose, a few coarse shallow punctures along edge of the frontal carina which is thin, sometimes feebly sinuate at middle and not reaching sides. Front rugose anteriorly, a few coarse punctures above the eyes and across the middle, base otherwise smooth. Pronotum convex, anterior angles acute, a little less than right angled, posterior angles rounded, sides finely margined, subparallel over basal half, strongly converging anteriorly, base not margined, sinuate, anterior median tubercle moderate, the depression or pit behind it moderately deep and distinct, its length from one-fourth to one-third the thoracic length, surface moderately coarsely punctate throughout, the punctures separated by from one to three times their diameters, those near and in the anterior depression slightly smaller. Scutellum smooth or with a few punctures. Elytra a little longer than wide, about twice as long as the pronotum; very fine punctures scattered throughout and mixed with coarse, deep and usually distinctly annular punctures, 
the annular punctures of the oblique geminate striae mostly separated by their diameter or less, those of the intervals about as close at the sides but less so on the disc, coarse punctures finer and closer posteriorly. Pygidium quite closely, finely to very moderately punctate throughout, the punctures separated generally by one to three times their diameters, sometimes less closely at apex, laterally finer and closer in the corners, at times almost scabriculate. Undersurface quite hairy, the strong prosternal process behind the front coxae completely so. Anterior tibia closely, finely, confusedly punctate just outside the longitudinal row of coarse setigerous punctures. Apex of hind tibia moderately flaring, its width less than half the length of the tibia measured along the inner edge. First segment of the posterior tarsus usually very little produced laterally, its apical width less than the length of the second segment. Aedeagus as in figure $5 b$.

Type: Probably lost. Through the kindness of Dr. Rene Malaise, the specimen purported to be the type of Scarabaeus gibbosus in the DeGeer collection in the Riksmuseum, Stockholm, was loaned to me for study. To my surprise I found it to be a specimen of Cyclocephala. This specimen could not possibly have been the type of Scarabaeus gibbosus DeGeer since it does not agree with the original description or the plate showing a rather poor drawing of the species. It does not have the anterior pronotal depression or pit mentioned in the original description and clearly indicated in the drawing. Further, it does not agree in size, color, or morphological characters as given in the original description. Dr. Malaise states there is no other specimen remaining in the DeGeer collection which could have been the type. The type of Scarabaeus gibbosus DeGeer must therefore be considered lost or destroyed.

Type locality: Pennsylvania.

Specimens examined: 2,700 .

Distribution: Typical gibbosus probably occurs in all States east of the Rocky Mountains except Florida and possibly Vermont, New Hampshire, and Maine. See map, figure 1.

CANAdA: Alberta: Wimborne. Ontario: Chatham, Essex Co., Point Pelee, Port Rowan. UNITED STATES: Alabama: Auburn, Birmingham, Decatur, 5 miles northeast of Eutaw (Green Co.), Florence, Mobile, Monroeville, Noccalula, Opelika, Selma, The Sinks (Bibb Co.), Tuscaloosa, Wadley. ArIzona: Portal, 6 miles southeast of Wilcox. Arkansas: Batesville, Boone, Booneville, Bentonville, Brinkley, Chicot Co., Cottonplant, Fayetteville, Hope, Imboden, Jonesboro, Marianna, Stuttgart, Washington Co. Colorado: Denver, Canon City, Fort Morgan (Morgan Co.), Golden, Kersay, Lamar, Littleton, Mill Gulch, Pueblo, Rocky Ford, Roggen, Two Buttes. Delaware: Bridgeville, Middleton, Newark, southern Delaware. District of Coldmbia. Georgia: Athens, Barnesville, Clarke Co., Cornelia, Danielsville, Eatonton, Experiment, Gainesville, Hartwell, Leesburg, MeRae, Prattsburg, Spalding Co., Sylvania (Screven Co.), Town Co., Umatilla, Wellston, Wenona. IDAHo: Pocatello. Illi$472591-59-2$ 
NoIs: Anna, Cairo, Carbondale, Champaign, Chester, Chicago, Danville, Decatur, Dixon Springs, Elizabethtown, Golconda, Harrisburg, Havana, Henry, Heyworth, Hillview, Industry, Kampsville, Knox Co., Metropolis, Mt. Carmel, Mt. Vernon, Normal, Peoria, Pittsfield, Pontiac, Putnam Co., Quincey, Taylorville, Urbana, West Frankfort. Indiana: Bluff, Clark Co., Henryville, Indianapolis, Lafayette, Lake Co., Madison, Marion Co., Miller, North Judson, Orleans, Posey Co., Spencer Co., Terre Haute, Vigo Co. Iowa: Ames, Cedar Rapids, Dennison (Crawford Co.), Independence, Iowa City, Keokuk, Mt. Pleasant, Missouri Valley, Muscatine, Sioux City. Kansas: Atchison, Clay Co., Douglas Co., Ford Co., Franklin Co., Garden City, Lakin, La Crosse, Lawrence,Newton, Reno Co., Scott City, Sylvia, Topeka, Wellington, Wichita. Kentucky: Dunmor, Fordville. Loursiana: Alexandria, Baton Rouge, Berwick, Covington, Franklin, Gueden, Leesville, Morgan City, Nacogdoches, North Iberia, Oliver, Orange, Ruston, Sunset. MARYLAND: Baltimore, Cabin John, College Park, Edgewood, Glen Echo, Hagerstown, Hyattsville, Kenwood Beach, Plum Point. Massachusetrs: West Springfield. Michigan: Ann Arbor, Base Line Lake, Charity Island, Dearborn, Delhi (Washtenaw Co.), Harbert Dunes (Berrien Co.), Ioseo Co., Ithaca, Livingston, Macomb Co., Midland Co., Mt. Clemens, Osceola Co., Pentwater, Rochester (Oakland Co.), Sawyer Dunes (Berrien Co.), Stevensville (Berrien Co.), Sturgis, Sumner, Van Buren Co., Whitmore Lake. Minnesota: Anoka Co., Big Lake, St. Paul. Mississippi: Greenwood, Jackson, Lafayette Co., Lucedale, Natchez. Missouri: Booneville, Charleston, Columbia, Concordia, Kimmswick, Lathrop, Louisiana, Overland, Rankin, Richmond, Rolla, St. Louis, Webster Groves, Williamsville. Nerraska: Ainsworth, Alliance, Ansley, Antioch (Sheridan Co.), Bradshaw, Broken Bow, Columbus, David City, Fairbury, Fairmont, Halsey, Holdrege, Lincoln, Marquette, Mackell (Dixon Co.), McCook, Mindon, Mitchell, Neligh, Norfolk, Ogallala, Omaha, O'Neill, Plainview, Ravenna, St. Edwards, Scottsbluff, Valentino, York. New Jersey: Atlantic City, Boonton, Hadden Heights, Jackson Mills, Lakehurst, Newark, Palmyra, Paterson, Rancocas Park, Somerset Co., Wildwood. New Mexico: Deming, Grants, Hot Springs-Las Vegas. New York: Babylon, Brooklyn, Long Beach, Montauk, Nepeague, Rock Beach, Rosedale. North Carolina: Brunswick Co., Carthage, Columbus Co., Durham, Fayetteville, Flat Rock, Goldsboro, Hendersonville, Hickey, Julian, Maxton, Morganton, Raleigh, Rica Square, Rocky Mount, Southern Pines, Statesville, Swain Co., Tewaceia, Tryon, Washington, Wendell, Whiteville, Wilson, Zebulon. OHго: Ashtabula, Cedar Point, Cincinnati, Columbus. Okrahoma: Bartlesville, Catoosa, Claremore, Comanche Co., Durant, Enid, Erick, Kenton (Cimarron Co.), La Verne (Harper Co.), Lawton, Muskogee, Okmulgee, Osage Co., South MeAlister, Springfield, Stillwater, Texas Co., Tulsa. Pennsylvania: Conshohocken, Gettysburg, Kennett Square, Lewisburg, Mt. Alto, Overbrook, Philadelphia, Reading, West Grove, York. Rhode Island: Providence. South Carolina: Aiken, Antreville, Batesburg, Bennetsville, Camden, Chester, Clemson, Columbia, Florence, Greenwood, Meredith, Monck's Corner, Pendleton, Sumter. South Daкота: Beresford, Britton, Brookings, Chamberlain, Claremont, Elk Point, Gregory, Hecla, Henry, Highmore, Hot Springs, Huron, Martin, Mobridge, Murdo, Pine Ridge, Pukwanna, Rapid City, Tyndall, Vermillion, Vernon, Winner. Tennessee: Athens, Burrville, Chattanooga, Dyersburg, Greenville, East Ridge, Jackson, Knoxville, McMinnville, Nashville, Sevierville. Texas: Amarillo, Barstow (Ward Co.), Brazos Co., Canadian, Canyon, Carthage, Childress, Chillicothe, College Station, Conroe, Corpus Christi, Dalhart, Dallas, Dickinson, Dimmit Co., Ellen, Fort Stockton, Fort Worth, Friona, Hereford, Hidalgo Co., Hopkins Co., Kerrville, Kingsville, Kirbyville, Laredo, Lufkin, Merit, Palo Doro State Park, Paris, Plainview, Ranger, Rusk, 
San Diego, Smith Co., Spearman, Spur, Sweetwater, Texarkana, Timpson, Trinity Co., Victoria, Waco, Wichita Falls, Winter Haven, Wolf City. VIRGinia: Amelia, Arlington, Cape Charles, Falls Church, Farmville, Fort Monroe, Great Falls, Nelson Co., Newport News, Norfolk, Pennington Gap, Petersburg, St. Yea, South Boston, Tappahannock, Williamsburg. Wisconsin: Black River Falls, Broadhead (Green Co.). Wroming: Wheatland, Platte Co.

Remarks: Bothynus gibbosus (DeGeer) was described from Pennsylvania in 1774 . Since no other species of similar appearance is known to occur in Pennsylvania, we can be reasonably sure of its identity even though the original description might apply to other species equally well.

It is surprising that this species does not occur in Florida, but among the many specimens seen from that State not one has been gibbosus. There have been a number of published records of gibbosus in Florida, notably Blatchley (1928). However, the only specimens labeled L. gibbosus (DeGeer) from Florida now remaining in the Blatchley collection are neglectus (LeConte).

\section{Bothynus gibbosus obsoletus LeConte}

Bothynus obsoletus LeConte, 1847, p. 87.

Ligyrus gibbosus obsoletus LeConte, 1856, p. 20.

Ligyrus californicus Casey, 1909, p. 283 (new synonymy).

Ligyrus spissipes Casey, 1909, p. 283 (new synonymy).

Ligyrus effetus Casey, 1915, p. 200 (new synonymy).

Ligyrus arizonensis Casey, 1915, p. 201 (new synonymy).

Ligyrus brevipes Casey, 1915, p. 202 (new synonymy).

Ligyrus laevicauda Casey, 1915, p. 202 (new synonymy).

Ligyrus laticollis Casey, 1915, p. 203 (new synonymy).

Ligyrus scitulus Casey, 1915, p. 203 (new synonymy).

Trpe: LeConte collection, Museum of Comparative Zoology, No. 3715 .

Type locality: Long's Peak, Colo.

Specimens examined: 1,856 .

Distributron: See map, figure 1. Of typical obsoletus:

United STATES: Arjzona: Adamana, Aztec, Camezon, Chiricahua Mts., Cottonwood, Ehrenberg, Flagstaff, Fredonia, Grand Canyon, Holbrook, Joseph City, Leupp, Littlefield, Mencopie (Cococino Co.), Navaho, Phoenix, 5 miles west of Portal, Prescott, Roll, Safford, Somerton, Tempe, Tuba, Tueson, Wellton, Wilcox, Winslow, Yuma. California: Alhambra, Apple Valley, Bakersfield, Banning, Bartow, Ben Lomond, Berkeley, Blythe, Borrego Springs, Burbank, Cajon Pass (San Bernadino Co.), Cathedral City, Chino, Clermont, Colton, Davis, Death Valley, Delhi, El Centro, El Monte, Fort Yuma, Fresno, Glendale, Hawthorne, Highgrove, Huntington Beach, Imperial Co., Indio, Island Mtn. (Trinity Co.), Jacumba, Kaweah, Lancaster, Lindsay, Loma Linda, Los Angeles, Los Banos, Midway, Modesto, Murray Dam (San Diego Co.), North Hollywood, Ontario, Olancha (Inyo Co.), Oro Grande, Oxnard, Palmdale, Palm Desert, Palm Springs, Pasadena, Playa del Rey, Porterville, Riverside Co., Rumsey, Sacramento, Salien Basin, San Bernadino, San Diego, San Fernando, Santa Barbara, 
Thousand Palms, Tracy, Ventura Co., Victorville, Visalia, Wescott, Whittier. Colorado: Long's Peak. Idaho: Boise, Caldwell, Freedom, Lewiston, Notus, Parma, Star. Nevada: Las Vegas. New Mexico: Alamogordo, Albuquerque, Drolets, Fort Wingate, Grand Canyon, Grants (Valencia Co.), Jemez Springs, Las Cruces, Lordsburg, Rodeo, Roswell. Oregon: Arlington, Biggs, Boardman, Corvallis, Dalles, Hermington, Island City, Ontario, Pendleton, Rufus, Umatilla. Texas: Davis Mts., El Paso, Fabans, Sierra Blanco (El Paso Co.), Van Horn. Uтан: Clinton, Delta, Farmington, Green River, Hooper, Hermiston, Kaysville, Knab, Layton, Moab, Oren, Pine Valley, Roy, St. George, Salt Lake City, Santa Clara, Spanish Fork, Syracuse, Wasatch Mts., Washington Co., Zion National Park. Washington: Dayton, Pasco, Pullman, Toppenish, Walla Walla, Wawawai, Wenatchee, Yakima. MEXICO: Aguascalientes: Aguascalientes. Baja California: Enzenada, San Felipe. Chindahua: 20 miles southwest of Camargo, Juarez, Marachee (10 miles south of Las Delicias), Ojo Laguna, Samalayuca, Santa Barbara. Durango: Durango. San Lois Potosf: San Luis Potosí, 30 miles southwest of San Luis Potosí. Sonora: Rocky Point. ZACATECA: San Alto.

Of specimens intermediate between gibbosus (DeGeer) and $o b$ soletus LeConte:

United STATes: Arizona: Bonita, Cochise Co., Douglas, Graham Mts., Phoenix, Portal, Tucson, Wilcox. Colorado: Crook, Fort Collins, Roggen. New Mexico: Albuquerque, Deming, Escondido, Jemez Mts., Lordsburg, Rodeo, State College, Thateher. Oкцанома: Tulsa. Texas: Alpine, Brewster Co., Costolon, Dalhart, Davis Mts., Ei Paso, Fort Davis, Presidio. MEXICO: Aguascalientes: Aguascalientes. Chinuahua: Arroyo Caterinas (15 miles south of Matamoros), 10 miles south of Las Delicias, Santa Barbara. Durango: Durango. San Luis Potosí: San Luis Potosí, 30 miles southwest of San Luis Potosí.

Remarks: Bothynus obsoletus LeConte is easily separated from typical gibbosus from the Eastern States. It is somewhat larger (11 to $20 \mathrm{~mm}$. in length), smoother in appearance with denser pilosity on the underside. The sides of the pronotum just under the margin are convex, at times so much so that the lateral margin anteriorly appears almost carniform. Posteriorly at sides and apex the punctures of the elytra become closer, finer, and nearer one size in obsoletus. The punctures of the pronotum and elytra are finer and usually not noticeably annular even in the elytral striae. The carina extending the elytral margin inward around the humerus is lower down and does not continue inward as far as in typical gibbosus. The posterior tibiae are short, heavy, and very wide apically, their width usually more than half the tibial length as measured along the inside edge. The first segment of the posterior tarsus is comparatively narrow basally and produced laterally at the apex, one side being nearly straight and the other noticeably sinuate in outline. Its width apically is frequently greater than the length of the second segment. Typical obsoletus is found in western Idaho, Washington, Oregon, 
California, Utah, Arizona, and New Mexico. Aedeagus as in figure $5 f$. West of the Rocky Mountains, specimens of obsoletus LeConte show very little variation. In southeastern Arizona, New Mexico, parts of Colorado, and western Texas in the Big Bend area, however, specimens are very frequently intermediate in character between typical obsoletus and gibbosus. Variations in the depth and form of the punctures, the length and width of the posterior tibiae and tarsal segments, and the convexity of the side margins of the pronotum are most noticeable. The degree of variation in each character differs in individual specimens to such an extent it is often quite impossible to decide which name should be applied. Because the characters used to separate the two forms tend here to merge or become intermediate in varying degree, I believe obsoletus should be considered a subspecies of gibbosus. LeConte (1856) called it a variety of gibbosus. Localities in which the more or less intermediate forms have been found are shown on the map (fig. 1). There are three typical specimens of obsoletus in the Casey collection bearing the locality label of Lincoln, Nebr., but I believe these are mislabeled. Casey had set them aside without determination. Two specimens labeled "Neb." were found in the Bolter collection, Illinois Natural History Survey.

\section{Bothynus morio LeConte}

Bothynus morio LeConte, 1847, p. 87.

Ligyrus morio LeConte, 1856 , p. 20.

Ligyrus longulus Casey, 1915, p. 193 (new synonymy).

Ligyrus virginicus Casey, 1915, p. 193 (new synonymy).

Ligyrus remotus Casey, 1915, p. 194 (new synonymy).

Length 12 to $16 \mathrm{~mm}$., width 7 to $9.5 \mathrm{~mm}$. Oblong, convex, shining, reddish brown to blackish brown. Clypeus apically bidentate, the teeth sharp and frequently almost spiniform, separated by about their basal width or slightly more surface slightly roughened anteriorly, smooth posteriorly in front of the thin, sharp, transverse, frontal carina, the carina slightly sinuate at middle and not reaching lateral margin. Head punctate-rugose behind carina, smooth basally. Pronotum as in gibbosus except that the anterior pit or depression is usually smaller and not so deep, and the punctures are usually much finer and not as deep. The elytra are slightly longer and the sides more nearly parallel than in gibbosus, with the coarse punctures finer and rarely noticeably annular. Pygidium with finer punctures throughout, fewer apically, very close to scabriculate laterally in the corners, and in the male at extreme base. Under surface hairy as in gibbosus, the prostemal process similarly completely covered with stiff hairs. Anterior tibia smooth and shining outside the longitudinal 
row of coarse setigerous punctures. Posterior tibia not as slender as in gibbosus, thicker through the middle and less flaring at the apex. Aedeagus as in figure $5 c$.

TyPE: Museum of Comparative Zoology, LeConte collection, No. 3716 .

TyPe LOCAlity: "Provinciis mediis."

Spectmens examined: 280.

Distribution: Ocean beaches and shores of rivers and bays near the ocean from Massachusetts to Texas. See map (fig. 4).

UNiTED STATES: Connecticut: Stamford, Westport. Florida: Bell Glade Capron, Crescent City, Edgewater, Enterprise, Kissimmee, Logger Head Key (Dry Tortugas), Long Key (Pinelas Co.), Marco, Miami, Miami Beach, Palm Beach, Pass-a-Grille, Ponte Vedra Beach, Sarasota, Titusville (Brevard Co.), Vilano Beach, Virginia Key (Dade Co.), Volusia, West Palm Beach. Georgia: St. Simons Island, Tybee Island. Louisiana: Grand Isle. Maryland: Chesapeake Beach, Dorchester Co., Kenwood Beach. Massachusetrs: Eastham, Harwichport, Nantucket, Plum Island Beach, Stoneham, Woods Hole. Mississippi: Gulfport, Horn Island. New Jersey. Anglesea, Avalon, Five Mile Beach, Island Beach, Ocean Beach, Salem, Sea Island City, Stone Harbor. New Yовк: Barren Island, Coney Island, Jones Beach, Long Island, Nepeague, Orient, Plum Beach, Rockaway. North Carolina: Beaufort, Cape Hatteras, Kill Devil Hill, Kitty Hawk, Long Beach. Rhode Island: Warwick, Watch Hill. South Carolina: Bulls Island, Charleston, Folly Beach, Hilton Head Island, Isle of Palms, Myrtle Beach, Seabrooks Island, Sullivans Island. Texas: Brownsville. Virginia: Cobb Island, Fort Monroe, Tappahannock, Virginia Beach. WEST INDIES: Bahama Islands: Allans Cay (Abaco Cays), Eleuthera Island, Grand Bahamas Island, Andros Island (Mangrove Cay), South Bimini.

Remarks: In general Bothynus morio LeConte is a smoother, slightly longer, and darker species than gibbosus, which it otherwise resembles. The smooth outer face of the anterior tibia (fig. $6 f$ ) is a character shared with neglectus LeConte, but whereas morio is more finely punctate and of smoother appearance than gibbosus, neglectus is much more coarsely punctate and rougher than gibbosus. The male genitalia of morio LeConte appears to be nearly identical with that of gibbosus (DeGeer) and the subspecies obsoletus LeConte. See figure 5. It is attracted to lights.

Some specimens of morio from Miami, Fla., have punctures much coarser than usual, but they still appear smoother than gibbosus and the foretibiae are smooth as is usual in the species. Perhaps these specimens provide an example of character displacement.

\section{Bothynus neglectus LeConte}

Bothynus neglectus LeConte, 1847, p. 87.

Ligyrus juvencus LeConte, 1856, p. 20 (not F'abricius, 1775, p. 32).

Ligyrus neglectus Casey, 1915, p. 198. 
Length 14 to $17 \mathrm{~mm}$., width 8 to $10 \mathrm{~mm}$. Oblong-oval, convex, shining, reddish brown. Clypeus apically bidentate, the teeth separated by about their basal width or a little more, surface finely rugose in front, nearly smooth posteriorly along the thin, sharp, frontal carina which does not reach the sides. Head shallowly coarsely punctate-rugose back of the carina, smooth at base. Pronotum convex, anterior angles sharp, less than a right angle, apex and sides margined, sides subparallel over basal half, strongly converging anteriorly, base sinuate, not margined, apical tubercle strong, depression back of it small, moderately deep, a little less than a third as long as pronotum; surface very coarsely, deeply punctate, punctures separated on the disc by about one diameter, along the base by several diameters, fewer in front and at extreme sides. Scutellum with a few scattered fine punctures. Elytra a little longer than wide, slightly wider posteriorly, punctures annular, deep and very coarse, those of the oblique geminate striae separated by about one diameter or less, punctures finer and closer at sides and apex, sometimes scattered extremely fine punctures evident throughout. Pygidium with fine scattered punctures separated by three or four diameters throughout, very finely scabriculate at sides and base in males. Undersurface somewhat hairy, the prosternal process completely covered apically with stifi hairs. Anterior tibia smooth, or rarely a few scattered fine punctures, remote from the longitudinal row of coarse setigerous punctures. Apex of hind tibia very moderately flaring, its apical width less than half the tibial length. Tarsi possibly a little more slender than in gibbosus (DeGeer). Aedeagus distinct (see fig. $6 d$ ).

Type: LeConte collection, Museum of Comparative Zoology, No. 3714 .

Type locality: Southern States, "provinciis australibus."

Specimens examined: 234.

Distribution: Coastal plain of Southeastern States, North Carolina to Louisiana. See map (fig. 2).

Alabama: Baldwin Co., Foley, Magazine Point, Mobile Co., Monroeville, Mt. Vernon, Wilmer. Florida: Alachua Co., Canal Point, Clewiston, Crescent City, De Funiak Springs, Dunedin, Elfers, Enterprise, Fort Lauderdale, Fort Myers, Gainesville, Hialeah, High Springs, Homestead, Kissimmee, Lake City, Largo, Leesburg, Levy Co., Madison Co., Marco, Melbourne, Miami, Monticello (Jefferson Co.), Orlando, Paradise, Quiney, Sanford, Tampa, Tarpon Springs, Welaka, Winter Park. Geongia: Bainbridge, Billy's Island (Okefenokee Swamp), Cordele, Newton, Screven Co., Thomasville, Waycross. Louisiana: Berwick. Mississippi: Gulfport, Lucedale. North Carolina: Brunswick Co., Hamlet, Long Beach, New Bern, Southern Pines, White Lake, Wilmington. South Carolina: Aiken, Allendale, Beaufort, Blackville, Cayce, Charleston, Columbia, Fairfax, McClellanville, Mt. Pleasant, Ridgeland, Yemassee. 

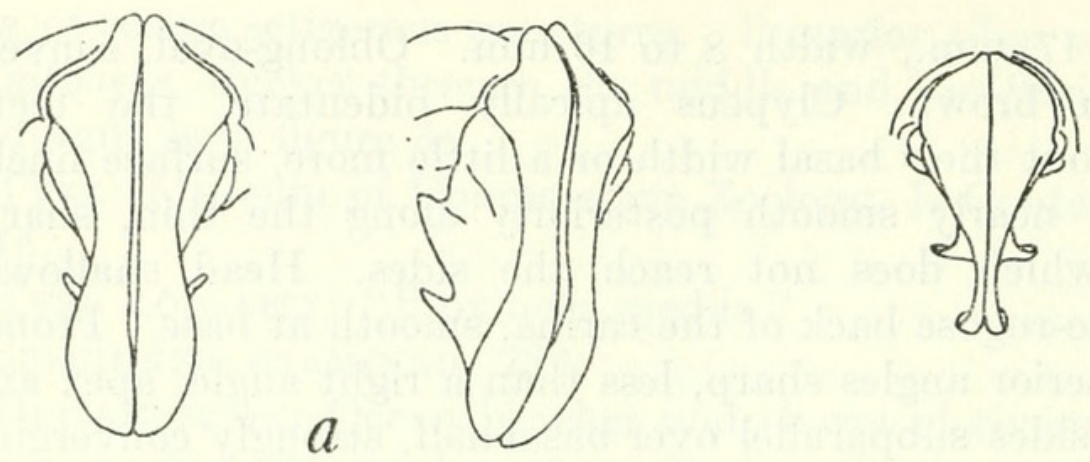

$b$
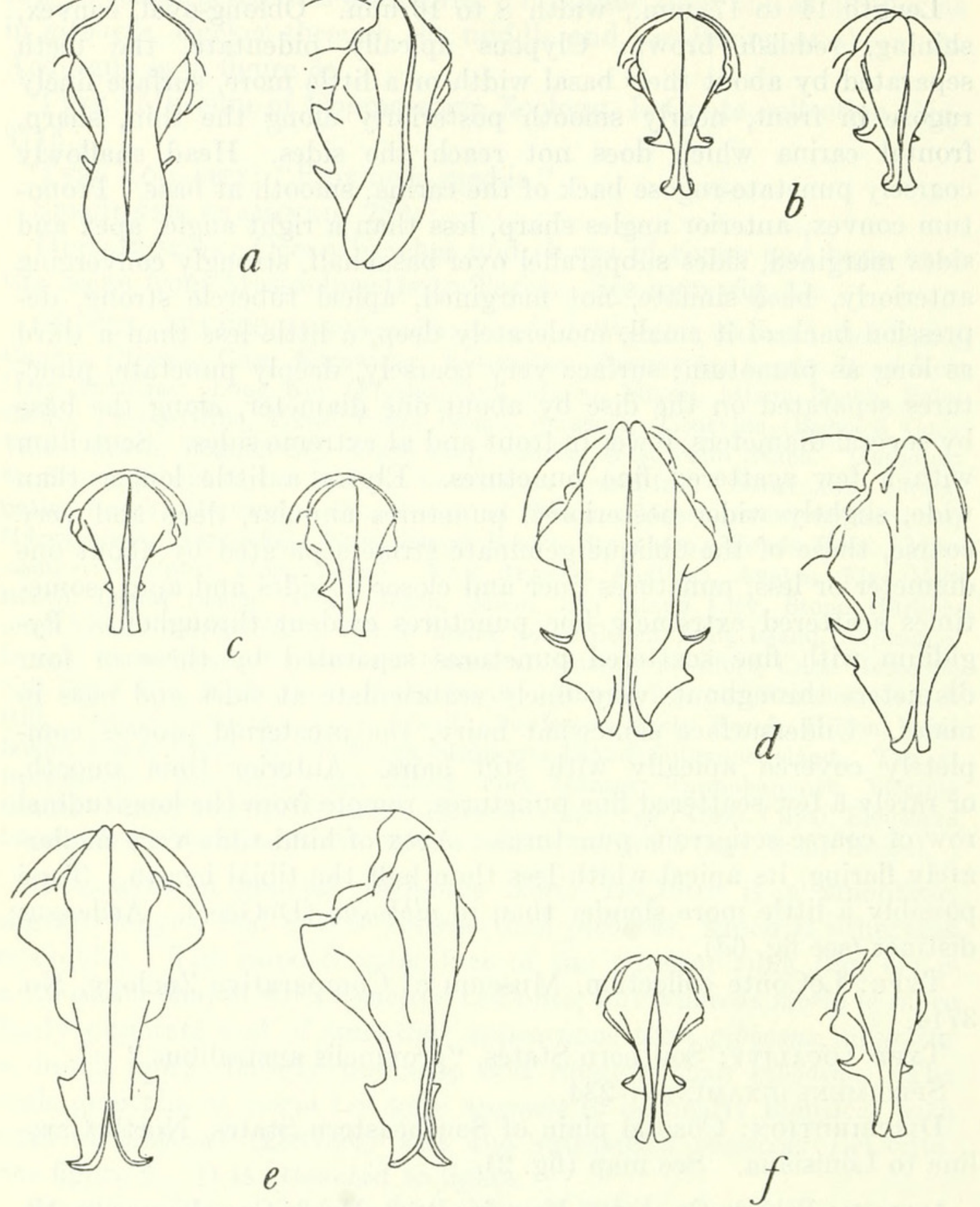

Figure 5.-Aedeagi of: a, Bothynus sallaei (Bates); b, B. gibbosus gibbosus (DeGeer); $c, B$. morio LeConte; $d, B$. subtropicus (Blatchley); $e, B$. selanderi, new species; $f, B$. gibbosus obsoletus LeConte.

Remarks: The very coarse punctures of the uppersurface and smooth anterior tibiae are the diagnostic characters for this species. It is very close to gibbosus (DeGeer) and morio LeConte but is easily separated from them. Casey included in his collection four specimens of neglectus in his series of gibbosus, a surprising and almost unbelievable error when we remember his keen observation and predeliction for describing species on minor variations. His collection contains a 

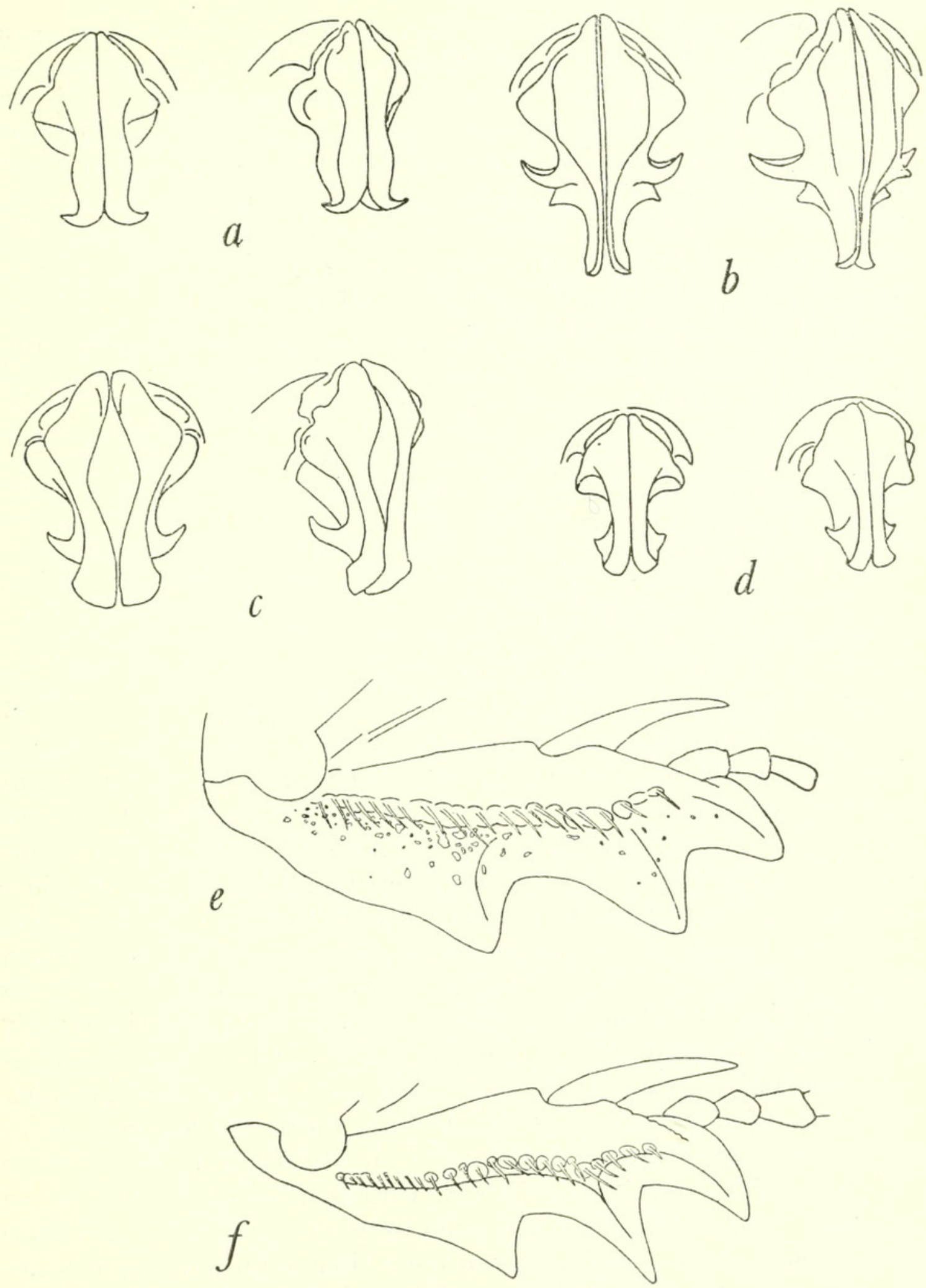

FigURE 6.-a-d, Aedeagi of: a, Bothynus cuniculus (Fabricius); b, B. laevicollis (Bates); $c, B$. relictus (Say); $d, B$. neglectus LeConte. $e, f$, Foretibia of: $e, B$. gibbosus gibbosus (DeGeer); $f, B$. morio LeConte.

single correctly identified specimen of neglectus and the four of the same species in the gibbosus series, specimens numbered $2,15,17$, and 18 . 
LeConte (1856) thought his neglectus was perhaps the same as juvencus Burmeister, 1847, and he was probably correct since Burmeister in his description of Podalgus variolosus (Bothynus gibbosus (DeGeer)) stated that the punctures were smaller than in his following species, P. juvencus. The Burmeister specimens were from South Carolina. However, the name juvencus was first used by Fabricius in 1775 for the species previously named gibbosus by DeGeer. Dr. Britton has very kindly compared specimens of gibbosus with the type of juvencus Fabricius in the Banks collection in the British Museum (Natural History) and states that juvencus Fabricius "agrees with your $L$. gibbosus, the front tibiae being obviously punctured outside the longitudinal row of setigerous punctures."

\section{Bothynus relictus (Say)}

Scarabaeus reliclus Say, 1825, p. 194.

Ligyrus relictus LeConte, 1856, p. 21.

Ligyrodes relictus Casey, 1915, p. 183.

Ligyrodes clypealis Casey, 1915, p. 181.

Ligyrodes parviceps Casey, 1915, p. 182.

Ligyrodes quadripennis Casey, 1915, p. 182.

Ligyrodes verncicollis Casey, 1915, p. 183.

Ligyrodes dawsoni Casey, 1924, p. 334.

Length 17 to $24 \mathrm{~mm}$., width 10 to $13 \mathrm{~mm}$. Oblong, convex, shining, dark reddish brown to piceous. Clypeus apically bidentate, the erect triangular teeth basally contiguous, surface finely, closely rugose. Head slightly concave, finely, closely rugose back of the thin, sharp, posteriorly directed, widely interrupted frontal carina which does not extend to the side margins, a few fine punctures above the eyes, base smooth. Pronotum convex, sides margined and evenly arcuate, converging anteriorly, base sinuate, without margin, apex without tubercle and depression; surface quite evenly yet irregularly moderately punctate throughout, punctures slightly smaller anteriorly, generally separated by one to four or five times their diameter. Scutellum with a few scattered fine punctures. Elytra with sides subparallel, disc coarsely, annularly punctate, these punctures finer and much closer at sides and apex, with fine punctures intermixed throughout, the coarse annular punctures of the oblique geminate striae separated by one diameter or less. Pygidium widely punctatescabrous basally and at sides, middle quite closely moderately to coarsely punctate, the punctures separated by one diameter or less to a little more than one diameter at apex. Underside anteriorly moderately hairy, the apex of the prosternal process behind the anterior coxae usually with a smooth, convex, anterior part separated from the hairy posterior part by a distinct groove. Anterior tibia smooth outside the longitudinal row of coarse setigerous punctures, 
males with claw segment swoolen, the anterior claw broad and abruptly bent at base. Aedeagus distinct (see fig. $6 c$ ).

TYPe: Probably destroyed.

Type locality: Pennsylvania.

Specimens examined: 953.

Distribution: Canada, north-central and northeastern United States. See map (fig. 3).

CANADA: Ontario: Amprion, Constance Bay, Ottawa, Marmora, Prince Edward Co., Queens Park, Rostrevor, Wellington. Manitoba: Aweme, Wawansea, Winnipeg. New Brunswick: Fredericton, St. John. Quebec: Aylmer, Como, Hull. UNITED STATES: Arizona: Cameron, Tueson. Arkansas: Fayetteville, Stittgart. Colorado: Boulder, Colorado Springs, Denver. Connecticut: Hamden, New Canaan, New Haven, Sheffield Isle, Stamford. Delaware: Newark, Wilmington. District of Columbia. Illinors: Algonquin, Antioch, Atwood, Champaign, Chicago, Cicero, Danville, Edgebrook, Evanston, Havana, Homer, Lacon, Lake Forest, Momence, Moline, Newton, Normal, Palos Park, Pittsfield, Riverside, Rock Island, Urbana. Indina: Lafayette, Laporte Co., Miller, Vigo., Warsaw. IowA: Ames, Carter Co., Clermont, Gruver, Independence, Iowa City, Kelso, Mt. Pleasant. Kansas: Atchison, Douglas Co., Lawrence, Manhatten, Mt. Hope, Reno, Riley Co., Sylvia, Wellington, Wichita. Marne: Augusta, Bar Harbor, Lincoln, Millinocket, Mt. Desert, Presque Isle, Round Pond. Maryland: Cambridge, Cecil Co., Edgewater. Massachusetrs: Cohasset, Dorchester, Nantucket, Wilmington, Woburn. Mrchigan: Ann Arbor, Bay Co., Berrien Co., Charity Isle, Duck Lake (Muskegan Co.), Detroit, Livingston Co., Manistee, Port Austin (Huron Co.), Richmond, Rochester (Oakland Co.), Sand Point (Huron Co.), Southfield (Oakland Co.), Whitefish Point (Chippewa Co.). Mrnnesota: Hennepin Co., St. Paul. Mrssouri: Boonville, Louisiana, St. Louis. Montana: State label only. Nebraska: Ainsworth, Bennet, Halsey (Thomas Co.), Lincoln, McCook, Neligh, Valentino. New Hampshree: Durham, Hampton. New Jersey: Avenel, Boonton, Brunswick, Hopateong, Island Beach, Madison, Newark, Paterson, Perth Amboy, Rahway, Seaside Park, Spring Lake, Woodbury. New York: Babylon, Brooklyn, Callicoon, Coronado Island, Elmhurst, Flatbush, Fort Totten, Hague, High Bridge, Long Beach, Long Island, Lyons (Wayne Co.), Nepeague, New Rochelle, Plattsburg, Potsdam, Rosedale, Staten Island, Unionport, West Point. North Carolina: Carthage, Southern Pines. North Dakota: Jamestown. Ohio: Buckeye Lake, Cedar Point. Oklahoma: El Reno, Norman, Optima, Stillwater. Pennsyluania: Beaver Falls, Canadensis, Jeanette, Lock Haven, Ohiopyle. Rhode Island: Warwick. South Dakota: Britton, Brookings, Capa, Chamberlain, Chester, Fort Thompson, Hecla, Highmore, Hill City, Hot Springs, Martin, Murdo, Oak Wood, Oldham, Pierre, Tyndall, Volga, Winner. Utah: Logan. Virginia: Arlington, Norfolk, Phoebus. Wisconsin: Brodhead (Green Co.), Madison, Milwaukee. Wyoming: Wheatland.

Remarks: Casey placed this species in a new genus, Ligyrodes, mainly because of the modification of the anterior tarsi in the male, nude apex of the postcoxal prosternal process, and different habitus of the body. Unfortunately, all of these characters are quite variable among the other species found south of the United States and it becomes impossible to separate them on the characters given. 
Whether Ligyrodes might be retained as a subgenus must be decided by a complete revision of the genus.

\section{Bothynus sallaei (Bates)}

Ligyrus sallaei Bates, 1888, p. 318.

Ligyrodes sallei Casey, 1915, p. 184.

Ligyrodes azlecus Casey, 1915, p. 184.

Ligyrodes propinquus Casey, 1915, p. 183.

Length 18 to $23 \mathrm{~mm}$., width 10 to $12 \mathrm{~mm}$. Oblong, convex, shining, dark red-brown to piceous. Clypeus apically bidentate, the upturned, triangular teeth usually contiguous at base, surface moderately rugose, not as finely or closely as in relictus (Say), Head slightly concave and similarly rugose back of the very widely interrupted frontal carina which does not extend to the lateral margins, the two parts directed posteriorly as in relictus but appearing more as blunt tubercles; basally smooth with a few fine punctures between and above the eyes. Pronotum convex, apically angulate at middle but without tubercle and depression, sides evenly arcuate, margined, anteriorly convergent, base sinuate without margin; surface with rather evenly distributed fine or moderate punctures which become coarser at sides and toward posterior angles, generally separated by two or more diameters, possibly a little finer and not as close as in relictus. Scutellum with a few scattered very fine punctures. Elytra only slightly wider behind, punctures as in relictus but not as coarse. Pygidium without scabrous sculpture except very narrowly at base in the male, coarsely punctate throughout, closely at base and sides, separated by less than their diameters, gradually sparser and finer apically. Underside anteriorly moderately hairy, the prosternal process back of the anterior coxae with a round, convex, smooth, shiny part in front set off from a posterior, flat, dull, smooth posterior part bordered by stiff hairs. Anterior tibia smooth outside the longitudinal row of coarse, setigerous punctures, a small, distinct, extra tooth between the second and third large teeth; male claw segment swollen, the anterior claw broad and abruptly bent at base. Aedegus distinct (see fig. 5a).

Lectotype: British Museum (Natural History).

Type locality: Almolonga, Mexico.

SPECIMENS EXAMINED: 151.

Distribution: Southern Texas and Mexico. See map (fig. 3).

UNITeD STATeS: Texas: Brownsville, Del Rio, Dimmit Co., Harlingen, Hidalgo Co., Houston, Kingsville, New Braunfels (Comal Co.), Robstown (Nueces Co.), Weslaco. MeXico: Chinuahua: Texcoco. Coamulla: La Babia (Tanque de Malone), Mosquiz (Río Sabinas). Federal District: Mexico City. Guerrero: Teloloapán. Mexicó: Chapingo. Morelos: Cuernavaca, Teguesquitengo. Nayarit: Jalisco, Tepic. Nuevo Lé́n: Monterrey. 
Puebla: Tehuacán. San Luis Potosí: Tamazunchale. Sinaloa: Mazatlán. Sonora: Agua Caliente (8 miles east of Zacatecas). Tamaulipas: Victoria Vera Cruz: Jalapa.

Remarks: Bothynus sallaei (Bates) may be recognized and separated from relictus (Say) by the shining, coarsely punctate pygidium and the small, distinct, extra tooth between the large second and third teeth of the anterior tibia.

\section{Bothynus cuniculus (Fabricius)}

Geotrupes cuniculus Fabricius, 1801, p. 20.

Scarabaeus antillarum Palisot de Beavois, 1805, p. 104.

Bothynus cuniculus Hope, 1837, p. 95.

Heteronychus tumulosus Burmeister, 1847, p. 101.

Ligyrus tumulosus Bates, 1888, p. 315.

Ligyrus cuniculus Arrow, 1937, p. 37.

Length 14 to $20 \mathrm{~mm}$., width 7 to $11 \mathrm{~mm}$. Oblong-oval, convex, shining, reddish brown to piceous. Clypeus apically bidentate, the erect triangular teeth widely spaced, separated by their basal width or more, surface finely closely rugose, the posteriorly directed frontal carina sinuate, strong and thin, widely interrupted at middle, joining lateral carina at sides. Head similarly rugose back of the carina, breaking into moderate punctures just in front of the smooth, shining occiput. Pronotum convex, with anterior and lateral margins as usual, base without margin, weakly sinuate, apical denticle small with a small, usually shallow depression behind it less than one-fourth the pronotal length; surface very evenly, finely to moderately punctate throughout, punctures everywhere separated by one to four times their diameters, the apical depression with a trace of rugose sculpture. Scutellum smooth, rarely with a few minute punctures. Elytra slightly wider behind the middle, moderately coarsely punctate, the punctures finely annular, very fine punctures intermixed throughout, the oblique geminate striae deep, their punctures usually separated by less than their diameters, all punctures finer laterally and apically. Pygidium coarsely, deeply punctate, slightly smaller apically, generally separated by one or two diameters. Underside anteriorly moderately hairy, prosternal process behind anterior coxae apically flat to convex, narrowly nude, the long stiff hairs encroaching from back and sides. Anterior tibia smooth outside the longitudinal row of coarse, setigerous punctures, claws normal. Male aedeagus distinct (see fig. 6a).

TyPe: Zoological Museum, Kiel, Germany.

Type locality: "America."

Specimens examined: 67 .

Distribution: Florida Keys and West Indies.

UNited STATES: Florida: Key West, Dry Tortugas. BERMUDA. WEST INDIES: Bahama Islands: Eleuthera, North Bimini, South Bimini, New 
Providence (Nassau), Andros, Barry (Fraziers Hog Cay). Barbados. Puerto Rico: Mayaguez, Ponce, Fajarda. Guadaloupe. Dominica: Roseau, Portsmouth. St. Vincent. Jamaica.

REMARKS: In addition to the specimens mentioned above I have seen a specimen labeled "Port Hope, Ontario. Dr. Bethune. Wickham Collection," and another labeled "Cal., H. F. W. Casey Collection." These two localities are so far from the known distribution it seems unwise to accept the label data without further confirmation.

The Alabama record of Ligyrus tumulosus Burmeister published in the Löding (1945, p. 108) list was based on a misidentified specimen of L. subtropicus Blatchley. I have examined the Löding specimens.

Burmeister described Heteronychus tumulosus from "Nord-Amerika (Sud-Carolina) und Westindien (St. Domingo)." The specimens labeled South Carolina may have been picked up on Bermuda on a voyage to or from the colony in South Carolina. The species does not occur in South Carolina.

\section{Bothynus laevicollis (Bates)}

Ligyrus laevicollos Bates, 1888, p. 316.-Schaeffer, 1909, p. 384.

Ligyrus bryanti Rivers, 1891, p. 97.

Length $2 \mathrm{i}$ to $26 \mathrm{~mm}$., width 12 to $14 \mathrm{~mm}$. Oblong, shining, piceus. Clypeus bidentate, the teeth practically contiguous at base, sides finely, sharply margined, front and clypeus finely rugose, frontal carina reduced to two widely separated, rather large, conical tubercles. Pronotum convex, finely margined apically and laterally, the slightly sinuate base without margin, apical median denticle small with a more or less triangular flat to very slightly concave, finely rugose area behind it, this area about one-fourth as wide as apical margin, apical angles acute; surface smooth and shining basally with very fine punctures becoming more evident at sides and gradually becoming fine to moderate in anterior angles where they are separated by about one diameter or less, occasionally a few are confluent. Scutellum smooth and shining with a few scattered minute punctures. Elytra 1 to $2 \mathrm{~mm}$. longer than wide, sides slightly divergent, widest slightly beyond the middle; humeral and apical umbones, first wide interval and narrow strip across base, smooth and shining with only scattered minute punctures, oblique geminate striae and remainder of disc coarsely, distinctly punctate, the punctures annular, evenly distributed, separated by one or two diameters in the intervals, punctures rapidly becoming fine to very fine and close laterally outside third pair of striae, apically beyond the umbone the punctures are close, mixed, fine and moderately coarse. Female pygidium with somewhat unevenly scattered but fairly closely spaced fine to moderate punctures 
throughout, scabriculate in corners and across base; male pygidium smooth, shining, minutely punctate apically, widely densely scabriculate laterally and basally. Underside sparsely hairy; prosternal process apically smooth and convex anteriorly, posteriorly and laterally clothed with long stiff hairs. Anterior tibia smooth in front, cariniform outside longitudinal row of coarse, setigerous punctures, scattered shallow, fine punctures beyond carina; tarsi normal. Male aedeagus distinct (see fig. $6 b$ ).

Lectotype: British Museum (Natural History).

Type locality: Acapulco, Guerrero, Mexico.

Specimens examined: 56.

Distribution :

United States: "Arizona." MeXiCO: Baja California: Cape San Lucas, San Felipe, San José del Cabo, Santa Rosa. Chiapas: Tapachula (cotype). Guerrero: Acapulco. Nayarit: San Blas. Sinaloa: Mazatlán.

Remarks: Bothynus laevicollis (Bates) is recognized by the very smooth, shining, first interval of the elytra. There seems to be no doubt that $L$. bryanti Rivers, described from Baja California, is identical. Dr. E. B. Britton of the British Museum (Natural History) very kindly supplied a cotype of $L$. laevicollis Bates for study. We have a series previously determined as L. bryanti from Baja California. No differences are discernible. The specimen from Phoenix, Aciz., determined as laevicollis by L. W. Saylor is not this species but is a female of the species described in this paper as Bothynus selanderi, new species.

\section{Bothynus selanderi, new species}

Ligyrus laevicollis Saylor, 1946, p. 44 (not Bates, 1888, p. 316).

Holotype male: USNM 63912. Length $28 \mathrm{~mm}$., width $14 \mathrm{~mm}$. Oblong, shining, piceous. Clypeus bidentate, the upturned teeth separated by about their basal width, clypeus and front continuously finely rugose, the rugae appearing as tiny ridges on a flat surface, i. e., not declivous on only one side, clypeal carina represented by two very widely spaced conical tubercles, more widely spaced than in laevicollis (Bates), occiput narrowly smooth. Pronotum convex, apically and laterally margined, base slightly sinuate, without margin, apical angles acute, apical denticle moderate with a shallow depression behind it less than one-fourth the length of the pronotum, a vague smaller depression about half as wide and half as deep on each side of the median depression; surface of median depression rugose, the rugae extending laterally to but not into the smaller depressions which are closely, distinctly punctate within, elsewhere the punctures are moderately coarse and deep on the disc just behind the median depression where they are separated by about their diameter, coarser, closer 
and shallower toward the anterior angles where the sculpture becomes more or less rugose, quite coarse toward the posterior angles, smoother and more finely punctate over the lateral fovea, and rapidly much finer and sparser basally at middle. Scutellum smooth with scattered indistinct, very fine punctures. Elytra elongate, sides subparallel, punctures mixed, very fine throughout, moderate in the oblique geminate striae and intervals, and with a very fine, vague, close, minute sculpture, not alutaceous, in addition, all punctures fine laterally and apically. Pygidium finely scabriculate in lateral angles and toward the middle basally, otherwise smooth and very finely and sparsely punctate throughout; more convex than in female. Underside sparsely hairy anteriorly, prosternal process behind anterior coxae with apex nude and convex anteriorly, with long hairs limited to sides and posterior part. Anterior tibia carinate and roughly, coarsely punctate outside the longitudinal row of coarse setigerous punctures, claws normal. Aedeagus distinct (see fig. $5 e$ ).

Allotype female: Length $29 \mathrm{~mm}$., width $14 \mathrm{~mm}$. Differs from the male in the shape of the pygidium, which is much less convex, with close, mixed fine and moderate punctures throughout, these superimposed on fine scabriculate sculpture along the base and in the lateral angles.

Type locality: Los Mochis, Sinaloa, Mexico, collected July 22, 1955, at light by R. B. and J. M. Selander.

PARATYPES: 38 males, 53 females, same data as holotype and allotype; 1 male, Los Mochis, Sinaloa, Mexico, July 25, 1922, C. T. Dodds; 3 males same locality and collector, July 20, 1922; 3 males, 1 female, Hermosillo, Sonora, Mexico, July 9-16, 1953, Borys Malkin; 1 male, Mazatlán, Sinaloa, Mexico, July 21, 1955, R. B. and J. M. Selander; 1 male, Esperanza, Sonora, Mexico, July 15, 1955, F. Pacheco-M., 1 female, Phoenix, Ariz., Aug. 10-20, 1908 (L. W. Saylor collection). See map (fig. 3).

Paratypes will be placed in the British Museum (Natural History), Riksmuseum, Canadian Department of Agriculture, American Museum of Natural History, California Academy of Sciences, Chicago Museum of Natural History, Frey Museum, Museum of Comparative Zoology, and in the private collections of L. J. Bottimer, W. W. Gibson, Henry Howden, Antonio Martinez, P. Francisco Silvario Pereira, Mark Robinson, and R. B. Selander.

Remarks: The typical series shows little variation. However, the shallow depressions on each side of the median, anterior, pronotal depression are more noticeable in some specimens; in some the coarse punctures of the wide interval between the sutural and first geminate striae become vague, shallow and almost obliterated by the other surface sculpture, in others the punctures remain distinct but shal- 
lower than the geminate series. The minute surface sculpture, in addition to the coarse and fine punctures, is much more noticeable in some specimens than others but is quite characteristic. Several have a more or less distinct, impunctate, narrow, longitudinal, median area over the basal half of the pronotum. The species ranges from 24 to $30 \mathrm{~mm}$. in length and 12 to $15 \mathrm{~mm}$. in width. It is quite similar to laevicollis (Bates) and subtropicus (Blatchley) but is easily separated from them by the male genitalia and characters given in the key. Bothynus selanderi is named in honor of R. B. Selander, who collected most of the typical series.

\section{Bothynus subtropicus (Blatchley)}

Ligyrus subtropicus Blatchley, 1922, p. 30.

Ligyrus blatchleyi Cartwright, 1944, p. 34.

Length 21 to $25 \mathrm{~mm}$., width 12 to $14 \mathrm{~mm}$. Oblong, convex, shining rufopiceous to piceous. Clypeus apically bidentate, the upturned, triangular teeth nearly contiguous at base, surface finely moderately closely rugose, the frontal carina represented by two low, widely spaced, more or less conical tubercles; front of head similarly rugose and slightly concave, the rugulose lines breaking to fine punctures posteriorly, occiput smooth. Pronotum convex with a low denticle on the anterior margin at middle and a flattened area or shallow depression behind it, the depression about one-third the pronotal length; sides margined, arcuate to acute anterior angles, base sinuate without margin; surface finely punctate over disc and at middle of base and sides, gradually much more coarsely punctate to the anterior and posterior angles, fine punctures at base separated by four or more diameters, coarse punctures in anterior angles generally by one diameter or less, the apical anterior depression rugose-punctate. Scutellum smooth or with a few fine punctures. Elytral sides subparallel, surface moderately coarsely punctate with very fine punctures intermixed throughout, the coarse, annular punctures of the oblique geminate striae and the intervals between somewhat coarser than those in the wide interval between the first geminate and sutural stria, all punctures finer and closer at sides and apex. Pygidium widely scabriculate-punctate at base and sides, only slightly less so in the female, otherwise shining and smooth with scattered very fine punctures, extreme apex virtually impunctate. Underside sparsely hairy anteriorly. Apex of prosternal process behind anterior coxae nude, smooth, only slightly convex, with the long, stiff hairs invading the area from sides and rear. Anterior tibia smooth and carinate outside the longitudinal row of coarse, setigerous punctures, claws unmodified. Male aedeagus distinct (see fig. $5 d$ ).

TyPE: Blatchley collection, Purdue University, Lafayette, Ind. 
Type locality: Dunedin, Fla.

Sfecimens examined: 69 , including holotype.

Distribution: Seacoast from North Carolina to Florida to Alabama. See map (fig. 3).

North Carolina: Wrightsville Beach. South Carolina: Charleston. Georgia: Savannah. Florida: Coconut Grove, Dade Co., Dunedin, Englewood, Everglades, Fort Lauderdale, Fort Myers, Homestead, Key Largo, Key West, Miami, South Miami. Alabama: Mobile Co.

Remarks: Saylor (1946) placed blatchleyi Cartwright in synonymy, as I surmised it might be in the original description. I have recently examined Blatchley's type of subtropicus and agree that his action was correct. Thus far this has been the only large species of Bothynus found in South Carolina, Georgia, and Florida.

\section{Literature Cited}

Arrow, G. J.

1937. In W. Junk and S. Schenkling, Coleopterorum Catalogus. Pars 156;

Scarabaeidae; Dynastinae; pp. 1-124.

Bates, Henry Walter

1888. Biologia Centrali-Americana. Insecta. Coleoptera. Vol. 2, pt. 2. Pectinicornia and Lamellicornia. Pp. 1-432, 21 pls.

Blatchley, W. S.

1922. Some new and rare Coleoptera from southeastern Florida. Canadian Ent., vol. 54, pp. 9-14, 27-33.

1928. The Scarabaeidae of Florida. Florida Ent., vol. 11, 1927, pp. 44-46; 1928 , pp. 55-62; continued through vols. 12,13 , and 14 to 1930.

Burmeister, HermanN

1847. Handbuch der Entomologie, vol. 5, pp. 1-584.

Cartwright, O. L.

1944. New Scarabaeidae from United States. Ann. Ent. Soc. Amer., vol. 37 , pp. 28-36.

Casey, Thos. L.

1909. Studies in the Caraboidea and Lamellicornia. Canadian Ent., vol. 41, pp. 253-284.

1915. A review of the American species of Rutelinae, Dynastinae and Cetoniinae. Memoirs on the Coleoptera, vol. 6, pp. 1-460.

1924. Additions to the known Coleoptera of North America. Memoirs on the Coleoptera, vol. 2, pp. 1-347.

\section{DeGeer, Charles}

1774. Mémoires pour servir a l'histoire des insectes. Vol. 4, pp. 1-456, 19 pls.

Erichson, W. F.

1847. Conspectus Insectorum Coleopterorum, quae in Republica Peruana observata sunt. Wiegmann's Archiv für Naturgeschichte, vol. 13, pp. 67-185.

FABricius, J. C.

1775. Systema entomologiae Insectorum. $832 \mathrm{pp.}$

1801. Systema Eleutheratorum. 506 pp. 
Hope, F. W.

1837. The Coleopterists manual, containing the lamellicorn insects of Linnaeus and Fabricius, pp. 1-121, 3 pls.

Krrby, William

1818. A century of insects, including several new genera described from his cabinet. Trans. Linn. Soc. London, vol. 12, pp. 375-453, illus.

Lacordaire, Jean Théodore

1856. Histoire naturelle des insectes. Coléoptères. Vol. 3, pp. 1-594, 39 pls.

LeConte, J. L.

1847. Fragmenta entomologica. Journ. Acad. Nat. Sci. Philadelphia, ser. 2, vol. 1, pp. 17-93.

1856. Notice of three genera of Scarabaeidae found in the United States, Proc. Acad. Nat. Sci. Philadelphia, vol. 8, pp. 19-25.

Löding, Henry Peter.

1945. Catalogue of the beetles of Alabama. Monograph 11, Geological Survey of Alabama. Pp. 1-172.

Palisot de Beaunois, A. M. F. J.

1805. Insectes recueillis en Afrique et en Amérique. 276 pp., 38 pls. Prell, Heinrich

1936. Beiträge zur Kenntnis der Dynastinen. Ent. Blatt., vol. 32, pp. 145-152.

Rrvers, J. J.

1891. New species of Scarabaeidae. Proc. California Acad. Sci., ser. 2, vol. 3, pp. 97-98.

Say, Thomas

1825. Descriptions of new species of coleopterous insects inhabiting the United States. Journ. Acad. Nat. Sci. Philadelphia, vol. 5, pp. 160-204.

SAYLOR, L. W.

1946. Synoptic revision of the United States scarab beetles of the subfamily Dynastinae, No. 3: Tribe Oryetini (part). Journ. Washington Acad. Sci., vol. 36, pp. 41-45.

Schaeffer, Charles

1909. New Coleoptera chiefly from Arizona. Bull. Brooklyn Inst. Arts Scl., vol. 1, pp. 375-386. 


\section{$2 \mathrm{BHL}$ Biodiversity Heritage Library}

Cartwright, Oscar Ling. 1959. "Scarab beetles of the genus Bothynus in the United States." Proceedings of the United States National Museum 108, 515-541. https://doi.org/10.5479/si.00963801.108-3409.515.

View This Item Online: $\underline{\text { https://www.biodiversitylibrary.org/item/32559 }}$

DOI: https://doi.org/10.5479/si.00963801.108-3409.515

Permalink: https://www.biodiversitylibrary.org/partpdf/7098

\section{Holding Institution}

Smithsonian Libraries

\section{Sponsored by}

Smithsonian

\section{Copyright \& Reuse}

Copyright Status: NOT_IN_COPYRIGHT

Rights: https://www.biodiversitylibrary.org/permissions/

This document was created from content at the Biodiversity Heritage Library, the world's largest open access digital library for biodiversity literature and archives. Visit BHL at https://www.biodiversitylibrary.org. 